\title{
DEER REDUCE HABITAT QUALITY FOR A WOODLAND SONGBIRD: EVIDENCE FROM SETTLEMENT PATTERNS, DEMOGRAPHIC PARAMETERS, AND BODY CONDITION
}

\author{
Chas A. Holt, ${ }^{1,2,3}$ Robert J. Fuller, ${ }^{1}$ and Paul M. Dolman ${ }^{2}$ \\ ${ }^{1}$ British Trust for Ornithology, The Nunnery, Thetford, Norfolk IP24 2PU, United Kingdom; and \\ ${ }^{2}$ School of Environmental Sciences, University of East Anglia, Norwich, Norfolk NR4 7TJ, United Kingdom
}

\begin{abstract}
Understanding avian responses to ungulate-induced habitat modification is important because deer populations are increasing across much of temperate Europe and North America. Our experimental study examined whether habitat quality for Blackcaps (Sylvia atricapilla) in young woodland in eastern England was affected by deer, by comparing Blackcap behavior, abundance, and condition between paired plots (half of each pair protected from deer). The vegetation in each pair of plots was the same age. The Blackcap is an ideal model species for testing effects of deer on avian habitat quality because it is dependent on dense understory vegetation and is abundant throughout much of Europe. We compared timing of settlement, abundance, age structure (second-year vs. after-second-year), and phenotypic quality (measured as a body condition index, body mass divided by tarsus length) between experimental and control plots. We used point counts to examine Blackcap distribution, and standardized mist netting to collect demographic and biometric data. Incidence of singing Blackcaps was higher in nonbrowsed than in browsed plots, and singing males were recorded in nonbrowsed plots earlier in the season, indicating earlier and preferential territory establishment. Most Blackcaps, both males and females, were captured in vegetation prior to canopy closure ( $2-4$ years of regrowth). Body condition was superior for male Blackcaps captured in nonbrowsed plots; for second-year males this was most marked in vegetation prior to canopy closure. We conclude that deer browsing in young woodland can alter habitat quality for understory-dependent species, with potential consequences for individual fitness and population productivity beyond the more obvious effects on population density. Received 3 May 2012, accepted 20 August 2012.
\end{abstract}

Key words: Blackcap, browsing, habitat use, Sylvia atricapilla, territory establishment.

\section{Los Ciervos Reducen la Calidad del Hábitat de un Ave Canora de Bosque: Evidencia de Patrones de Asentamiento, Parámetros Demográficos y Condición Corporal}

Resumen.-Entender la respuesta de las aves a la modificación del hábitat inducida por los ungulados es importante porque las poblaciones de ciervos están aumentando a través de buena parte de las zonas templadas en Europa y Norte América. Nuestro estudio experimental examinó si la calidad del hábitat de Sylvia atricapilla en bosques jóvenes del oriente de Inglaterra se ve afectada por los ciervos mediante una comparación del comportamiento, la abundancia y la condición corporal de S. atricapilla en parcelas pareadas (la mitad de cada par estaba protegida de los ciervos). La vegetación en cada par de parcelas era de la misma edad. La especie $S$. atricapilla es un modelo ideal para evaluar los efectos de los ciervos sobre la calidad del hábitat de las aves debido a que depende de vegetación densa de sotobosque y es abundante en casi toda Europa. Comparamos los tiempos de establecimiento, la abundancia, la estructura de edad (segundo año vs. después del segundo año) y la calidad fenotípica (medida como un índice de condición corporal, masa corporal dividida por la longitud del tarso) entre parcelas experimentales y parcelas control. Usamos conteos por puntos para examinar la distribución de S. atricapilla y redes de niebla estándar para recolectar los datos demográficos y biométricos. La presencia de individuos de S. atricapilla cantando fue mayor en las parcelas no ramoneadas que en las ramoneadas, y los machos fueron detectados cantando más temprano en la temporada en las parcelas no ramoneadas, lo que indica un establecimiento de territorio temprano y preferencial. La mayoría de individuos, tanto machos como hembras, fueron capturados en vegetación en la que aún no se había cerrado el dosel ( 2 a 4 años de crecimiento). La condición corporal de los machos capturados en parcelas no ramoneadas fue superior; para los machos de segundo año, este patrón fue más marcado en la vegetación en la que aún no se había cerrado el dosel. Concluimos que el ramoneo de los ciervos en bosques jóvenes puede alterar la calidad del hábitat de las especies dependientes del sotobosque, con consecuencias potenciales para la aptitud individual y la productividad de las poblaciones que van más allá de los efectos obvios sobre la densidad poblacional.

${ }^{3}$ E-mail: chas.holt@bto.org

The Auk, Vol. 130, Number 1, pages 13-20. ISSN 0004-8038, electronic ISSN 1938-4254. @ 2013 by The American Ornithologists' Union. All rights reserved. Please direct all requests for permission to photocopy or reproduce article content through the University of California Press's Rights and Permissions website, http://www.ucpressjournals. com/reprintInfo.asp. DOI: 10.1525/auk.2012.12090 
Negative effects of intensified browsing associated with increasing deer populations are especially profound for bird species that depend on understory vegetation (Allombert et al. 2005, Holt et al. 2011, Martin et al. 2011). However, with the exception of radiotracking of Common Nightingales (Luscinia megarhynchos; Holt et al. 2010), the effects of deer browsing appear to have been examined solely in terms of the relative abundance, density, or incidence of birds. Although such studies have shown profound differences in occupancy and relative abundance between browsed and nonbrowsed vegetation, this may nevertheless underestimate the effects of deer on habitat quality. Within the range of habitat structures occupied by a species, variation in habitat quality may be reflected in differential pairing status, phenotypic quality, or breeding productivity of territory-holding individuals, with important demographic consequences (Brown 1969, Gill et al. 2001).

As a general principle, breeding birds select the most suitable habitat that will allow them to successfully reproduce (Cody 1985), but the association between habitat selection and habitat quality can be complex because abundance alone is not necessarily a correlate of habitat quality (Van Horne 1983, Fletcher 2007). However, differences in habitat quality can be inferred from settlement preferences and condition of territory holders (Morris 1992, Johnson 2007). Through competition at settlement, dominant individuals and those of higher phenotypic quality tend to occupy high-quality habitats for breeding (Lundberg et al. 1981, Sutherland 1996, Hallworth et al. 2008). Furthermore, in migrant species, seasonal matching of habitat quality and fitness has been demonstrated (Gunnarsson et al. 2005), with associated effects on reproductive success (e.g., Norris et al. 2004). The age, size, and body condition of breeding adult passerines are all considered to reflect individual quality or social dominance (Kempenaers et al. 1992, Doutrelant et al. 2000, Kipper et al. 2006) and, hence, can be used to infer habitat quality (Johnson 2007). Superior habitat quality may be inferred from earlier settlement of males and an increased proportion of full adults as opposed to subadultsas demonstrated, for example, in studies of the Willow Warbler (Phylloscopus trochilus; Foppen and Reijnen 1994) and the Pied Flycatcher (Ficedula hypoleuca; Huhta and Jokimäki 2001). Compared to subadult individuals, older adults may exhibit higher reproductive success, arrive earlier on breeding grounds, compete more effectively for high-quality territories, and show greater site fidelity (e.g., Holmes et al. 1996, Hoover 2003, Hallworth et al. 2008), although these patterns vary according to the context of the breeding population (e.g., Dale and Steifetten 2011).

The Blackcap (Sylvia atricapilla) is one of the most abundant species of migrant passerines that use the understory layer of European temperate woodlands (Hagemeijer and Blair 1997), and it will use a range of shrub species. For example, Elder (Sambucus nigra) is preferred in the Czech Republic (Weidinger 2000), but bramble (Rubus spp.) has been shown to be the main nesting substrate for the species in Poland (Węgrzyn and Leniowski 2011), Iberia (Carbonell et al. 2003), and Britain (Mason 1976). Węgrzyn and Leniowski (2011) showed that nest survival was greater in bramble than in other shrub species (including Elder). In Spain, Blackcap density was better predicted by a dense understory, particularly bramble cover, than by any other habitat variable (Carbonell and Tellería 1998). Many studies have shown that the presence of deer reduces bramble cover (e.g., Morecroft et al.
2001, Stone et al. 2004, Gill and Fuller 2007). Hence, strong selection of bramble by browsing deer has the potential to influence the abundance and distribution of Blackcaps (and other bird species with similar habitat requirements) beyond the simple modification of understory and subcanopy vegetation. Given its relatively high abundance, the Blackcap is an ideal model species for examining the effects of deer browsing on understory birds.

We examined phenotypic quality and habitat use by male and female Blackcaps over a 3-year period as part of an experiment in regenerating woodland in eastern England. By comparing nonbrowsed vegetation inside fenced exclosures with that in adjacent paired control plots exposed to deer, we tested the effects of deer browsing on Blackcaps by examination of (1) timing of territory establishment, (2) demographic composition (i.e., second-year [SY] vs. after-second-year [ASY] birds), and (3) biometrics and body condition. Our hypotheses were (1) that Blackcaps would respond positively to vegetation within plots protected from deer and (2) that individuals in unbrowsed plots would establish territories earlier, be in better condition, and comprise a greater proportion of ASY individuals.

\section{Methods}

Study area.-Bradfield Woods National Nature Reserve (Suffolk, eastern England) is a coppiced wood of 64 ha, managed for nature conservation. Coppicing is an ancient form of woodland management whereby stands are cut on a rotation and woody vegetation regenerates from multistemmed stumps that are long-lived and persist through management cycles (Rackham 2003). Bradfield Woods is managed using a 25-year cutting cycle; an average $( \pm$ SD) of $1.15 \pm 0.45$ ha has been cut each year between 1998 and 2008. Relatively tall English Oak (Quercus robur), European Ash (Fraxinus excelsior), and birch (Betula spp.) trees are scattered at low density among the lower coppiced trees that are mainly European Ash, birch, Common Hazel (Corylus avellana), and European Alder (Alnus glutinosa). Marked increases in the numbers of native Roe Deer (Capreolus capreolus) and invasive Reeves's Muntjac (Muntiacus reevesi) have occurred at the site and in the surrounding landscape since the early 1990s (Fuller 2001). During the 2000s, Fallow Deer (Dama dama) also colonized the area.

Between 1999 and 2003, eight deer exclosures were erected at Bradfield Woods. During each of the 5 years, one or two exclosures were constructed in coppice newly cut that winter, fully protected from deer by $1.8-\mathrm{m}$-high steel fences. In a splitplot experimental design, each exclosure plot was paired with an adjacent area of similar size cut at the same time (hereafter "control plot"). Within each split-plot, exclosure and control plots were randomly assigned. Hence, eight experimental coppice pairs were formed; mean $( \pm \mathrm{SD})$ area of exclosures was $0.42 \pm$ 0.13 ha (range: $0.22-0.63 \mathrm{ha}$ ) and that of controls was $0.55 \pm 0.21$ ha (range: $0.33-0.85$ ha). The split-plot design of paired exclosure and control within an individual coppice stand minimized preexisting differences in vegetation structure and composition, and the density of mature trees was similar between exclosures and controls (Holt et al. 2011). The range of vegetation ages sampled during the course of the present study was 2 to 9 years. Further details of the Bradfield Woods experiment are given in Holt et al. $(2010,2011)$. 


\section{Sampling Blackcaps}

Point counts.-Within each exclosure and control plot, four 5-min point counts were carried out between 0530 and 0930 hours GMT during April and May in 2005, 2006, and 2007. Five-minute point counts are considered appropriate for surveying birds in woodland (Fuller and Langslow 1984, Drapeau et al. 1999). All male Blackcaps seen or heard within a fixed radius of $25 \mathrm{~m}$ were recorded (Hutto et al. 1986), centered on the midpoint of each exclosure or control plot. In all plots, the edge of the recording area was $\geq 10 \mathrm{~m}$ from the plot boundary. In each year, a point-count was carried out in the periods 8-15 April, 20-29 April, 1-9 May, and 11-22 May, so that timing of settlement and territory establishment could be determined.

On each visit, the exclosure and control plots in each experimental coppice pair were visited in the reverse order to the previous visit. Counts were not conducted in rain or strong wind ( $>4$ on Beaufort scale). Given the juxtaposition of the exclosures and controls, the possibility of recording the same individual birds during different point counts could not be ruled out. A single observer with extensive experience observing birds in lowland British woodland (C.A.H.) undertook all the surveys, avoiding any possibility of biases due to observer performance. Registrations were based on audible contact as opposed to sightings; the possibility that vegetation age or browsing intensity could have affected detection probability was considered negligible in such a small radius.

Mist netting.-Blackcaps were also sampled by standardized mist netting in each of the 3 years. Two $18-\mathrm{m}$ mist nets were sited in a straight line in the center of each exclosure and each control plot; capture efficiency did not differ between plots (Holt et al. 2011). The plots were sampled four times each year, with a visit to each experimental coppice pair in each of the following four periods: 23 May-7 June, 10-25 June, 3-18 July, and 20 July-3 August. Further details of the standardized mist netting are given in Holt et al. (2011). Data from the first and second visits, classified as the breeding season, were used in the present study.

All Blackcaps were banded with an individually numbered aluminium British Trust for Ornithology band. Age, sex, tarsus length $( \pm 1 \mathrm{~mm}$ ), wing length (maximum chord to nearest $\mathrm{mm}$; Redfern and Clark 2001), and mass $( \pm 0.1 \mathrm{~g})$ were recorded. Tracheal pit fat score (range: 0-8) and pectoral muscle condition score (range: 0-3) (Kaiser 1993) were also recorded, and females were examined for the presence of a brood patch and males for a cloacal protuberance, both of which indicate breeding activity. Hour of capture was recorded.

Aging.-In Blackcaps, SY individuals (i.e., adults in the calendar year following fledging) of both sexes can be visually distinguished from ASY individuals because of the presence of a molt limit arising from a partial postjuvenile molt during the preceding autumn. This limit is most often visible between molted greater coverts (with greenish edges) and one or two retained juvenile greater coverts and alula (with brownish edges) (Jenni and Winkler 1994). Other features often exhibited by SY birds are a molt limit within the tertials, or between the secondaries and tertials, and, on males, the retention of brown juvenile feathers on the black crown. ASY Blackcaps do not exhibit such molt limits, tend to have a more reddish iris, and also possess tail feathers that have more rounded tips than typical SY individuals (Jenni and Winkler 1994). Although it is acknowledged that ASY individuals can be more challenging to age with certainty, all Blackcaps that did not exhibit at least one of the characteristics of SY listed above were assumed to be ASY. Probable and definite
ASY birds were pooled for analysis of the effects of vegetation age and experimental treatment, supported by morphometric similarity between these two classes (see results of morphometric analysis). Juvenile Blackcaps, hatched in the current breeding season, are readily distinguishable from older birds by the freshness of their plumage and active body molt (e.g., Jenni and Winkler 1994).

Hereafter, the three demographic groups of Blackcaps are referred to as ASY, SY, and juveniles, respectively. Biometrics of ASY and SY individuals were compared between vegetative growth stages, and exclosure and control plots, for individuals captured during the breeding season (represented by pooled data from visits 1 and 2). Biometrics and body condition of juveniles captured during the post-breeding period were not examined, because these birds may not yet have been fully grown.

\section{Data Analysis}

Classification of vegetation age.-Distribution of bird species in regenerating deciduous woodland is largely determined by the growth stage and associated structural characteristics of the vegetation (Fuller 1995). In all analyses, effects of vegetation age were considered using two classes, 2-4 years and 5-9 years (defined as the number of full summers of vegetation regrowth prior to the start of the respective current breeding season). In coppiced woodland these represent pre- and post-canopy-closure, respectively (e.g., Fuller et al.1989, Fuller and Henderson 1992), and this is the most parsimonious classification of vegetation age for statistical modeling of Blackcap abundance at Bradfield Woods (Holt et al. 2011).

Territory establishment.-The relative occurrence of male Blackcaps across the experiment was examined separately for each pointcount visit period using generalized linear mixed models (GLMMs) in SAS, version 9.2 (SAS Institute, Cary, North Carolina). Whether male Blackcaps were recorded on each point-count visit per plot was analyzed in terms of presence-absence, using a binomial error distribution and a logit link function. Browsing and vegetation age were treated as fixed effects. The GLIMMIX procedure was used, allowing inclusion of random effects of plot and year to control for potential non-independence due to repeated measurements of the same plots across years, as well as potential variation in timing of arrival of migrant Blackcaps between years. We fitted additional models to explicitly test temporal variation in response, in which all visits were included and browsing, vegetation age, visit period, and the browsing $\times$ visit period interaction were treated as fixed effects. We performed pairwise comparisons between individual visit periods and also fitted a model comparing the response of Blackcaps in the first visit period with that in subsequent periods pooled.

Demographic composition.-For each sex, the relative numbers of ASY and SY Blackcaps captured in mist-netting visits were compared among browsing treatments and vegetation age classes using a GLMM. Total captures of Blackcaps per plot during each breeding season were treated as dependent variables in separate sex- and age-specific models for the four combinations of male and female, ASY and SY. Browsing, vegetation age, and their interaction were treated as fixed effects. The interaction term was retained where $P<0.1$. Poisson error and log link function were employed within the GLIMMIX procedure, with plot and year included as random effects. Whether the relative abundances of ASY and SY Blackcaps differed in relation to experimental treatment or coppice age was examined by including interactions between bird age and deer, and 
between bird age and vegetation age. We also fitted a further model, separately for males and females, which used the proportion (arcsin square-root transformed) of ASY among pooled SY and ASY captures (per plot per breeding season) as the dependent variable, with normal error and identity link function specified; plot-seasons with no Blackcap captures were excluded.

Biometrics and body condition.-We examined whether biometric measures (wing length, tarsus length, and mass) differed for Blackcaps captured in plots exposed to deer, or in coppice of different age, by using sex- and age-specific GLMMs that treated deer browsing and vegetation age as fixed effects. Various approaches have been used by researchers to examine body condition of organisms (Peig and Green 2010); we used a simple index of body mass divided by tarsus length (following Lambrechts et al. 2004) to test for differences in body condition, using the same sex- and age-specific model structure. We employed a normal error distribution for all measures, with plot and year treated as random effects. The use of sex- and agespecific tests increases the reliability of condition indexing methods (Peig and Green 2010), thereby minimizing the need to apply a scaled mass index (e.g., Peig and Green 2009). Further sex-specific GLMMs were used to test for differences in fat and pectoral muscle scores between the experimental areas. We used the following a priori criteria in all analyses: $P<0.01=$ highly significant, $P<0.05=$ significant, and $P<0.1=$ marginally significant .

\section{Results}

Timing of arrival and territory establishment.-Male Blackcap song territories were established in exclosures before those in control plots. During the first point-count visit period of the spring, the incidence of singing males was $\sim 3 \times$ greater in exclosures than in controls (Fig. 1 and Table 1). This contrast diminished in later visit periods, presumably as later-arriving birds progressively settled in controls. There was a marginally significant difference in the response to browsing between the first visit and subsequent pooled visits $(F=3.26, \mathrm{df}=1$ and $185, P=0.072)$, and pairwise comparisons

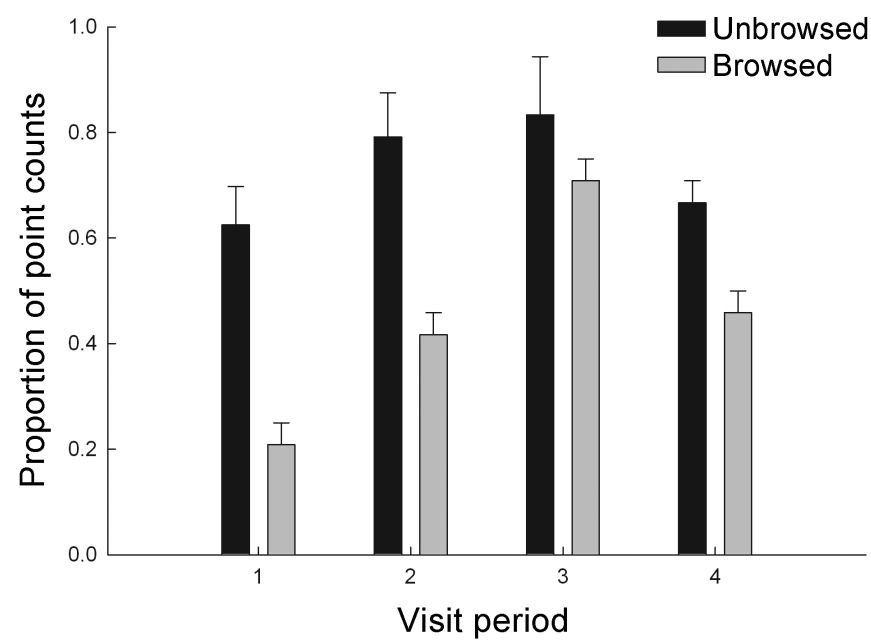

FIG. 1. Temporal variation in frequency of singing male Blackcaps at Bradfield Woods split-plots in 2005-2007. Mean proportions of pointcounts when males were recorded $( \pm$ SE) in nonbrowsed exclosures (black bars) and browsed control plots (gray bars) are shown. Incidence is shown in relation to visit period. Visit periods: (1) 8-15 April, (2) 20-29 April, (3) 1-9 May, and (4) 11-22 May.
TABLE 1. Generalized linear mixed models of incidence of male Blackcaps at Bradfield Woods split-plots in 2005-2007, as recorded during point-count visit periods. Modeled effects (binomial error, logit link) of deer browsing ${ }^{a}$ and vegetation age ${ }^{b}$ on presence-absence of singing males in each split-plot are shown, separately for each of four visit periods. Browsing * vegetation age interaction was not retained $(P>0.1$ in all models). Models also included random effects of year and plot.

\begin{tabular}{llrrrr}
\hline & & $\beta$ & $\chi^{2}$ & df & $P^{c}$ \\
\hline 8-15 April & Browsing & $-3.200 \pm 0.963$ & 11.05 & 1 and 43 & $0.002^{* * *}$ \\
& Vegetation age & $0.811 \pm 1.032$ & 0.62 & 1 and 43 & 0.436 \\
20-29 April & Browsing & $-1.410 \pm 0.620$ & 5.18 & 1 and 43 & $0.028^{* *}$ \\
& Vegetation age & $0.380 \pm 0.619$ & 0.38 & 1 and 43 & 0.543 \\
1-9 May & Browsing & $-1.371 \pm 0.715$ & 3.68 & 1 and 43 & $0.062^{*}$ \\
& Vegetation age & $0.447 \pm 0.901$ & 0.25 & 1 and 43 & 0.622 \\
11-22 May & Browsing & $-1.435 \pm 0.625$ & 5.26 & 1 and 43 & $0.027^{* *}$ \\
& Vegetation age & $-0.485 \pm 0.865$ & 0.31 & 1 and 43 & 0.578 \\
\hline
\end{tabular}

a Selection for browsed vegetation indicated by a positive parameter estimate.

b Selection for younger, pre-canopy-closure vegetation indicated by a positive parameter estimate.

$c * P<0.1, * * P<0.05, * * * P<0.01$.

between individual visit periods showed a significant temporal difference in response to browsing between periods 1 and 3 (browsing * visit period interaction; $F=4.60, \mathrm{df}=1$ and $89, P=0.035$ ).

Demographic composition.-A total of 130 ASY or SY Blackcaps (excluding same-year retraps) were captured during standardized mist netting. These comprised 83 males (29 ASY, 54 SY) and 47 females (30 ASY, 17 SY). The proportion of ASY per plot was unrelated to browsing in both males $(F=0.79, \mathrm{df}=1$ and $32, P=0.38)$ and females $(F=1.75, \mathrm{df}=1$ and $26, P=0.20)$. Similarly, the proportion of ASY per plot was unrelated to vegetation age in males $(F=0.08$, $\mathrm{df}=1$ and $32, P=0.78)$ and females $(F=0.20, \mathrm{df}=1$ and $26, P=0.66)$.

Significantly more male (SY and ASY) and female (ASY) Blackcaps were captured in young vegetation prior to canopy closure than in older vegetation (Table 2). Numbers captured did not differ between exclosures and control plots for any of the sex- or age-specific classes, and there was no effect of the interaction between deer and vegetation age (Table 2).

TABLE 2. Generalized linear mixed models of numbers of captures of after-second-year (ASY) and second-year (SY) Blackcaps (per plot, per breeding season) at Bradfield Woods in 2005-2007. Separate models are presented for males $(\hat{O})$ and females $(\$)$. Modeled effects (Poisson error, log link) of browsing a and vegetation age ${ }^{\mathrm{b}}$ are shown; browsing * vegetation age interaction term was not retained $(P>0.1)$. Models include random effects of year and plot.

\begin{tabular}{|c|c|c|c|c|c|}
\hline & & $\beta$ & $\chi^{2}$ & $d f$ & $P^{c}$ \\
\hline ASY 0 & Browsing & $-0.789 \pm 0.539$ & 1.52 & 1 and 44 & 0.218 \\
\hline$(n=29)$ & Vegetation age & $0.435 \pm 0.484$ & 3.67 & 1 and 44 & $0.055^{*}$ \\
\hline SY ${ }^{\lambda}$ & Browsing & $0.208 \pm 0.373$ & 2.00 & 1 and 44 & 0.157 \\
\hline$(n=54)$ & Vegetation age & $0.520 \pm 0.434$ & 5.99 & 1 and 44 & $0.014^{* *}$ \\
\hline ASY ${ }_{+}$ & Browsing & $0.000 \pm 0.500$ & 0.00 & 1 and 44 & 1.000 \\
\hline$(n=30)$ & Vegetation age & $0.754 \pm 0.518$ & 4.08 & 1 and 44 & $0.043^{* *}$ \\
\hline SY $q$ & Browsing & $0.847 \pm 0.690$ & 0.30 & 1 and 44 & 0.586 \\
\hline$(n=17)$ & Vegetation age & $1.175 \pm 0.764$ & 1.35 & 1 and 44 & 0.246 \\
\hline
\end{tabular}

Selection for browsed vegetation indicated by a positive parameter estimate.

b Selection for pre-canopy-closure vegetation indicated by a positive parameter estimate.

c $P<0.1,{ }^{* *} P<0.05, * * * P<0.01$. 
Biometric measures and body condition.-Male Blackcaps classified in the field as probable ASY $(n=18)$ had wing length (mean $\pm \mathrm{SD}=75.2 \pm 1.90 \mathrm{~mm}$ ) and mass $(16.9 \pm 0.86 \mathrm{~g}$ ) similar to those of definite ASY ( $n=11$; wing length, $75.9 \pm 1.90 \mathrm{~mm}$; mass, $16.5 \pm 0.43 \mathrm{~g}$ ) (Tukey post hoc tests, $P>0.1$ ), but both metrics differed significantly in comparison to definite SY birds $(n=54$; wing length, $73.8 \pm 1.83 \mathrm{~mm}$; mass, $16.3 \pm 0.80 \mathrm{~g}$ ) (Tukey tests, $P<0.05$ ). This supports the pooling of probable and definite ASY males for analysis. No differences in wing length and mass were detected between the age classes of females (Tukey tests, $P>0.1$ ).

Raw biometric measures did not differ between plots of different vegetation age, apart from significantly greater mass of SY males in pre-canopy-closure vegetation and of ASY males in areas from which deer were excluded (Table 3 ). The index of body condition showed that SY males captured in plots prior to canopy closure were in better condition. Similarly, ASY males captured in areas from which deer were excluded were in significantly better body condition than those captured in browsed control plots (Fig. 2 and Table 3). Females showed no difference in body condition between browsed and nonbrowsed areas. Both ASY males and ASY females exhibited (marginally significant) longer wing lengths in browsed control plots. There was no difference in fat (males: $F=0.19, P=$ 0.667; females: $F=1.25, P=0.270$ ) or pectoral muscle scores (males: $F=0.36, P=0.553$; females: $F=1.39, P=0.245$ ) between browsed and nonbrowsed plots (probably owing to insufficient variation as a result of the relatively coarse scoring categories used).

\section{Discussion}

Blackcaps in regenerating woodland in eastern England showed differential habitat selection resulting from deer-mediated effects, and morphological differences between individuals settling in browsed in comparison to nonbrowsed vegetation. There was evidence of earlier territory establishment and superior body condition of males in nonbrowsed vegetation. These results strongly suggest that woodland habitat quality for Blackcaps was superior in the absence of deer.

Inferences of habitat quality.-Behavioral responses that lead to differences in habitat selection by birds are complex, but earlier territory establishment by Blackcaps in nonbrowsed vegetation was probably in response to a denser understory and greater bramble cover (Carbonell and Tellería 1998, Remeš 2003, Węgrzyn and Leniowski 2011) found within the Bradfield Woods exclosures compared with the browsed control plots (Stone et al. 2004, Gill and Fuller 2007, Holt et al. 2011). Weidinger (2000) showed that Blackcaps breed earlier at sites with earlier leafing of the shrub layer. By using foliage density as a cue at the time of territory establishment, migrant songbirds can reliably secure food resources for nestlings (Marshall and Cooper 2004).

Male Blackcaps in vegetation without deer were of superior body condition (and ASY individuals weighed more) compared with counterparts captured in browsed vegetation, which infers phenotypically limited segregation due to habitat quality mediated by browsing. We acknowledge that a potential tradeoff between foraging dominance and predator avoidance may predict that lighter birds would occur in relatively open understory vegetation, such as that generated by both browsing and canopy closure (Holt et al. 2011), due to energetic constraints of provisioning for young and also greater predator risk (e.g.,

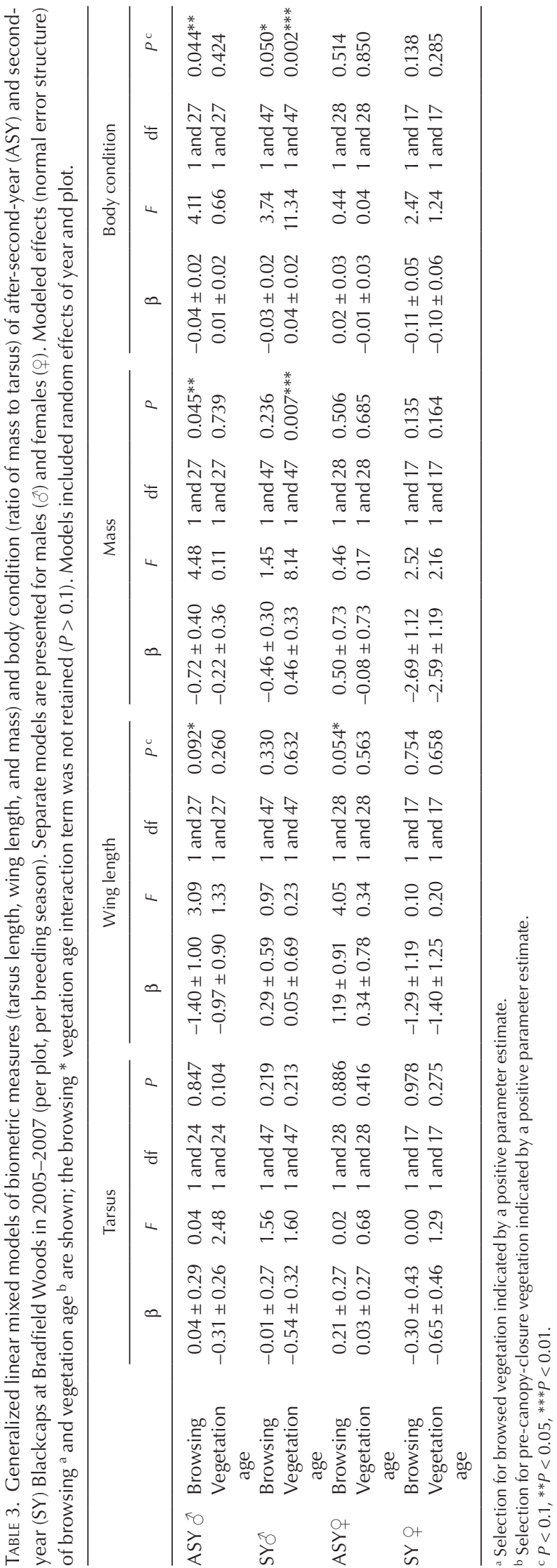



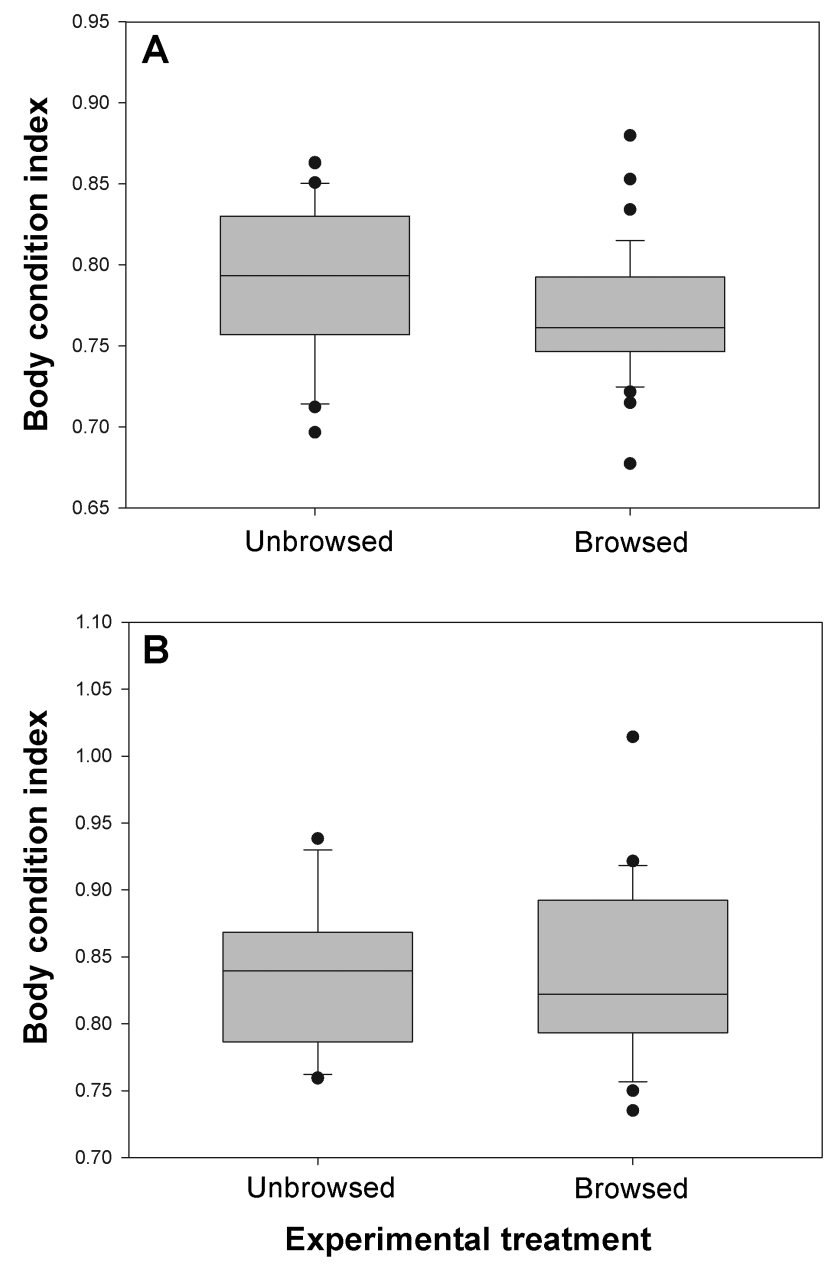

FIG. 2. Distribution of Blackcaps at Bradfield Woods split-plots in 2005-2007, for (A) males and (B) females, in unbrowsed exclosures and browsed control plots, in terms of body condition (mass in relation to tarsus length). For each sample, the box indicates the interquartile range, with median value shown by horizontal line. The whiskers encompass $95 \%$ of the range of the data, with outliers denoted by black dots.

Lima 1985, Gosler et al. 1995). However, the inference that body condition reflects bird quality concurs with our results concerning territory settlement, particularly considering the small spatial scale of the study site. All else being equal, both parameters suggest that birds of superior quality occupied plots of superior habitat quality.

In terms of demographic composition, we captured a relatively large number of SY males (65\% of all males captured), across plots containing a range of territory densities, including some plots where conventional mapping techniques indicated an absence of territorial birds (R. J. Fuller unpubl. data). A sex ratio biased toward males is typical in wild bird populations (Donald 2007), and the presence of nonsinging individuals can indicate the presence of floaters (e.g., Bayne and Hobson 2001). Floaters are generally considered to be males that arrive relatively late to breeding areas and either set up territories in suboptimal habitat but remain unpaired or fail to acquire either a territory or partner (Huhta and Jokimäki 2001). Nonterritorial floaters may spend time wandering among territory holders, possibly sampling potential habitat in advance of settlement the following year (Dale et al. 2006).

In contrast to territory mapping, the use of mist netting provides an overall index of habitat use by birds and is an appropriate sampling method from which to infer relative patterns of activity. Although we detected no effect of deer browsing in terms of the number of Blackcaps captured, ASY males inside exclosures were in superior body condition compared with counterparts in browsed plots, and SY males in young vegetation were in superior body condition compared with birds in vegetation after canopy closure. These results are suggestive of a response to the quality of foraging conditions, associated with denser shrub layers both where deer are excluded and in vegetation prior to canopy closure (Holt et al. 2011).

Potential effects of territoriality on habitat use.-In view of the spatial distribution and juxtaposition of exclosure and control plots at Bradfield Woods, we cannot be certain where Blackcaps either nested or foraged. However, three times as many nests of Blackcaps or Garden Warblers (Sylvia borin; nests of these two species are superficially similar) were found inside the exclosures (36 nests) compared with the control plots (11 nests) during standardized searches in the winters of 2005-2006 and 2006-2007 (R. J. Fuller and C. A. Holt unpubl. data). This difference was presumably because of a denser bramble cover within the exclosures (Gill and Fuller 2007, Holt et al. 2011), a habitat characteristic favored by Blackcaps (e.g., Węgrzyn and Leniowski 2011). Virtually all nests found were in bramble, but we acknowledge that it is possible, albeit unlikely, that nests might persist longer there than in other situations. Furthermore, Holt et al. (2010) demonstrated with the use of radiotracking that territorial male Common Nightingales spent the majority of their time in plots at Bradfield Woods where they were originally captured, and areas of song territories and core kernel home ranges were broadly similar. It is reasonable to assume that territory-owning male Blackcaps behaved similarly and probably ranged less than unpaired counterparts.

Older males are expected to occupy the best-quality territories and produce more offspring than SY males (e.g., Lozano and Lemon 1999, Carrete et al. 2006), and inter-annual site fidelity is often considered a good indicator of habitat quality (Johnson and Sherry 2001, Brown et al. 2002, Dale et al. 2006). However, too few Blackcaps were recaptured between years to allow us to examine patterns of site fidelity at Bradfield Woods.

Our results demonstrate important differences in habitat quality that arose from browsing by deer at densities typical of the wider landscape. Initial territory settlement by Blackcaps in the best-quality areas was followed by subsequent settlement in lower-quality areas, whereas individuals using nonbrowsed vegetation (richest in resources) were of better phenotypic quality. This provides strong support that subtle effects of deer browsing on habitat quality, and therefore potentially on demographic performance, can extend beyond the more commonly observed effects on species incidence or population density.

In order to better understand the reasons behind population changes of woodland birds, further studies examining the biological mechanisms and demographic processes underlying the responses to various environmental changes, including browsing, are required. As far as we are aware, this is the first study to have examined responses to deer-induced habitat change in woodland 
by investigation of bird settlement patterns, abundance, demographics, and body condition. By demonstrating that browsing can have negative consequences on habitat quality for understorydependent bird species, these results are an important contribution to a growing body of evidence concerning the ecological implications of increasing deer populations.

\section{ACKNOWLEDGMENTS}

We are grateful to P. Fordham and Suffolk Wildlife Trust for continued support with research at Bradfield Woods National Nature Reserve, where Natural England kindly granted permission to carry out mist-netting studies. The exclosure fences were constructed with funds made available from the UK Heritage Lottery Fund. A. Bull and D. de Palacio provided assistance in the field, and A. Johnston and G. Siriwardena provided statistical advice. Field work was partly funded by the British Trust for Ornithology's Nightingale Appeal. We particularly thank C. Elphick and three anonymous reviewers for their comments on the manuscript.

\section{Literature Cited}

Allombert, S., A. J. Gaston, And J.-L. Martin. 2005. A natural experiment on the impact of overabundant deer on songbird populations. Biological Conservation 126:1-13.

BAYNE, E. M., AND K. A. Hobson. 2001. Effects of habitat fragmentation on pairing success of Ovenbirds: Importance of male age and floater behavior. Auk 118:380-388.

Brown, D. R., C. M. Strong, and P. C. Stouffer. 2002. Demographic effects of habitat selection by Hermit Thrushes wintering in a pine plantation landscape. Journal of Wildlife Management 66:407-416.

Brown, J. L. 1969. The buffer effect and productivity in tit populations. American Naturalist 103:347-354.

Carbonell, R., J. Pérez-Tris, and J. L. Tellería. 2003. Effects of habitat heterogeneity and local adaptation on the body condition of a forest passerine at the edge of its distributional range. Biological Journal of Linnean Society 78:479-488.

Carbonell, R., and J. L. Tellería. 1998. Selección y uso del hábitat por cinco poblaciones ibéricas de Curruca Capirotada (Sylvia atricapilla). Ardeola 45:1-10.

Carrete, M., J. A. Sánchez-Zapata, J. L. Tella, J. M. Gil-SÁnchez, And M. Moleón. 2006. Components of breeding performance in two competing species: Habitat heterogeneity, individual quality and density-dependence. Oikos 112:680-690.

Cody, M. L., Ed. 1985. Habitat Selection in Birds. Academic Press, London.

Dale, S., And $\varnothing$ Steifetten. 2011. The rise and fall of local populations of Ortolan Buntings Emberiza hortulana: Importance of movements of adult males. Journal of Avian Biology 42:114-122.

Dale, S., Ø. Steifetten, T. S. Osiejuk, K. Losak, and J. P. Cygan. 2006. How do birds search for breeding areas at the landscape level? Interpatch movements of male Ortolan Buntings. Ecography 29:886-898.

Donald, P. F. 2007. Adult sex ratios in wild bird populations. Ibis 149:671-692.
Doutrelant, C., J. Blondel, P. Perret, and M. M. LamBRECHTS. 2000. Blue Tit song repertoire size, male quality and interspecific competition. Journal of Avian Biology 31:360-366.

Drapeau, P., A. LeduC, AND R. MCNeIL. 1999. Refining the use of point counts at the scale of individual points in studies of birdhabitat relationships. Journal of Avian Biology 30:367-382.

FLetCher, R. J., JR. 2007. Species interactions and population density mediate the use of social cues for habitat selection. Journal of Animal Ecology 76:598-606.

Foppen, R., AND R. REIJNEN. 1994. The effects of car traffic on breeding bird populations in woodland. II. Breeding dispersal of male Willow Warblers (Phylloscopus trochilus) in relation to the proximity of a highway. Journal of Applied Ecology 31:95-101.

Fuller, R. J. 1995. Bird Life of Woodland and Forest. Cambridge University Press, Cambridge, United Kingdom.

Fuller, R. J. 2001. Responses of woodland birds to increasing numbers of deer: A review of evidence and mechanisms. Forestry 74:290-298.

Fuller, R. J., And A. C. B. Henderson. 1992. Distribution of breeding songbirds in Bradfield Woods, Suffolk, in relation to vegetation and coppice management. Bird Study 39:73-88.

Fuller, R. J., AND D. R. LANGSLOw. 1984. Estimating numbers of birds by point counts: How long should counts last? Bird Study 31:195-202.

Fuller, R. J., P. Stuttard, and C. M. Ray. 1989. The distribution of breeding songbirds within mixed coppiced woodland in Kent, England, in relation to vegetation age and structure. Annales Zoologici Fennici 26:265-275.

Gill, J. A., K. Norris, P. M. Potts, T. G. Gunnarsson, P. W. AtKinson, and W. J. Sutherland. 2001. The buffer effect and large-scale population regulation in migratory birds. Nature 412:436-438.

Gill, R. M. A., AND R. J. Fuller. 2007. The effects of deer browsing on woodland structure and songbirds in lowland Britain. Ibis 149 (Supplement 2):119-127.

Gosler, A. G., J. J. D. Greenwood, and C. Perrins. 1995. Predation risk and the cost of being fat. Nature 377:621-623.

Gunnarsson, T. G., J. A. Gill, J. Newton, P. M. Рotts, and W. J. Sutherland. 2005. Seasonal matching of habitat quality and fitness in a migratory bird. Proceedings of the Royal Society of London, Series B 272:2319-2323.

Hagemeijer, E. J. M., And M. J. Blair, Eds. 1997. The EBCC Atlas of European Breeding Birds: Their Distribution and Abundance. T \& A D Poyser, London.

Hallworth, M., A. Ueland, E. Anderson, J. D. Lambert, and L. Reitsma. 2008. Habitat selection and site fidelity of Canada Warblers (Wilsonia canadensis) in central New Hampshire. Auk 125:880-888.

Holmes, R. T., P. P. Marra, And T. W. Sherry. 1996. Habitatspecific demography of breeding Black-throated Blue Warblers (Dendroica caerulescens): Implications for population dynamics. Journal of Animal Ecology 65:183-195.

Holt, C. A., R. J. Fuller, and P. M. Dolman. 2010. Experimental evidence that deer browsing reduces habitat suitability for breeding Common Nightingales Luscinia megarhynchos. Ibis 152:335-346.

Holt, C. A., R. J. Fuller, And P. M. Dolman. 2011. Breeding and post-breeding responses of woodland birds to modification of habitat structure by deer. Biological Conservation 144:2151-2162. 
Hoover, J. P. 2003. Decision rules for site fidelity in a migratory bird, the Prothonotary Warbler. Ecology 84:416-430.

Hunta, E., AND J. JокIмÄKI. 2001. Breeding occupancy and success of two hole-nesting passerines: The impact of fragmentation caused by forestry. Ecography 24:431-440.

Hutto, R. L., S. M. Pletschet, and P. Hendricks. 1986. A fixedradius point count method for nonbreeding and breeding season use. Auk 103:593-602.

Jenni, L., AND R. WinkLer. 1994. Moult and Ageing of European Passerines. Academic Press, London.

Johnson, M. D. 2007. Measuring habitat quality: A review. Condor 109:489-504.

Johnson, M. D., AND T. W. SherRy. 2001. Effects of food availability on the distribution of migratory warblers among habitats in Jamaica. Journal of Animal Ecology 70:546-560.

KAISER, A. 1993. A new multi-category classification of subcutaneous fat deposits of songbirds. Journal of Field Ornithology 64:246-255.

Kempenaers, B., G. R. Verheyen, M. Van den Broeck, T. Burke, C. Van Broeckhoven, And A. A. Dhondt. 1992. Extra-pair paternity results from female preference for high-quality males in the Blue Tit. Nature 357:494-496

Kipper, S., R. Mundry, C. Sommer, H. Hultsch, and D. Todt. 2006. Song repertoire size is correlated with body measures and arrival date in Common Nightingales, Luscinia megarhynchos. Animal Behaviour 71:211-217.

Lambrechts, M. M., S. Caro, A. Charmantier, N. Gross, M.-J. Galan, P. Perret, M. Cartan-Son, P. C. Dias, J. Blondel, AND D. W. Thomas. 2004. Habitat quality as a predictor of spatial variation in Blue Tit reproductive performance: A multi-plot analysis in a heterogeneous landscape. Oecologia 141:555-561.

LiMA, S. L. 1985. Maximizing feeding efficiency and minimizing time exposed to predators: A trade-off in the Black-capped Chickadee. Oecologia 66:60-67.

LOZANO, G. A., AND R. E. LEMON. 1999. Effects of prior residence and age on breeding performance in Yellow Warblers. Wilson Bulletin 111:381-388.

Lundberg, A., R. V. Alatalo, A. Carlson, and S. Ulfstrand. 1981. Biometry, habitat distribution and breeding success in the Pied Flycatcher Ficedula hypoleuca. Ornis Scandinavica 12: 68-79.

Marshall, M. R., AND R. J. CoOper. 2004. Territory size of a migratory songbird in response to caterpillar density and foliage structure. Ecology 85:432-445.
Martin, T. G., P. Arcese, and N. Scheerder. 2011. Browsing down our natural heritage: Deer impacts on vegetation structure and songbird populations across an island archipelago. Biological Conservation 144:459-469.

Mason, C. F. 1976. Breeding biology of the Sylvia warblers. Bird Study 23:213-232.

Morecroft, M. D., M. E. Taylor, S. A. Ellwood, and S. A. QUINN. 2001. Impacts of deer herbivory on ground vegetation at Wytham Woods, central England. Forestry 74:251-257.

MORRIS, D. W. 1992. Scales and costs of habitat selection in heterogeneous landscapes. Evolutionary Ecology 6:412-432.

Norris, D. R., P. P. Marra, T. K. Kyser, T. W. Sherry, and L. M. RATCLIFFE. 2004. Tropical winter habitat limits reproductive success on the temperate breeding grounds in a migratory bird. Proceedings of the Royal Society of London, Series B 271:59-64.

Peig, J., And A. J. Green. 2009. New perspectives for estimating body condition from mass/length data: The scaled mass index as an alternative method. Oikos 118:1883-1891.

Peig, J., AND A. J. GReEn. 2010. The paradigm of body condition: A critical reappraisal of current methods based on mass and length. Functional Ecology 24:1323-1332.

Rackнам, O. 2003. Ancient Woodland: Its History, Vegetation and Uses in England, 2nd ed. Castlepoint Press, Dalbeattie, United Kingdom.

Redfern, C. P. F., AND J. A. Clark. 2001. Ringer's Manual, 4th ed. British Trust for Ornithology, Thetford, United Kingdom.

REMEŠ, V. 2003. Effects of exotic habitat on nesting success, territory density, and settlement patterns in the Blackcap (Sylvia atricapilla). Conservation Biology 17:1127-1133.

Stone, J., P. M. Dolman, ANd R. J. Fuller. 2004. Impacts of deer grazing on regenerating coppice stools and ground flora: An exclosure study in Bradfield Woods, England. Quarterly Journal of Forestry 98:257-262.

Sutherland, W. J. 1996. From Individual Behaviour to Population Ecology. Oxford University Press, Oxford, United Kingdom.

VAn Horne, B. 1983. Density as a misleading indicator of habitat quality. Journal of Wildlife Management 47:893-901.

WĘGRZYN, E., AND K. LENIOWSKI. 2011. Nest site preference and nest success in Blackcaps Sylvia atricapilla in Poland. Ardeola 58:113-124.

WEIDINGER, K. 2000. The breeding performance of Blackcap Sylvia atricapilla in two types of forest habitat. Ardea 88:225-233.

Associate Editor: C. Elphick 